\title{
The Symptoms of Impaired Lung Function and Its Determinants Analysis on Garment Workers at UD. Surabaya Jember Region
}

\author{
Mayang Sari Eka Sriwahyuningsih ${ }^{1}$, Ancah Caesarina Novi Marchianti², Hadi Prayitno ${ }^{3}$ \\ ${ }^{1}$ Graduate Student, Magister Program of Public Health Education, Jember University, East Java (Indonesia), \\ ${ }^{2}$ Medical Doctor, Philosophy of Doctor, Faculty of Medicine, Jember University, East Java (Indonesia), \\ ${ }^{3}$ Lecturer at Faculty of Social Science and Political Science, Jember University, East Java (Indonesia)
}

\begin{abstract}
Lung disease due to work is a disease or disorder that occurs due to the inhalation of dangerous particles, mists, vapors or gases while someone is working. UD. Surabaya is an informal garment industry making apparel in the city of Jember which has several processes including cutting, sewing, and finishing. As many as 5 out of 10 workers who were randomly interviewed said that they experienced respiratory problems such as shortness of time at work, and 3 workers suffered from symptoms of lung function disorders after 10 years of work. The aim of research was to analyze symptoms of impaired lung function on garment workers at UD. Surabaya Jember District. The data used in this research were primary data which have been collected from questionnaire to 108 worker respondents. The analysis instrument was technique of regression of weight through AMOS software. The result of instrument testing concluded that all variables were valid and reliable as the instruments of data collection. The result of data analysis referred that: 1) the individual characteristics have positive effect to the symptoms of impaired lung function, 2) the amount of exposure contact have positive effect to the symptoms of impaired lung function on garment workers, 3 ) the indicators of individual characteristic which affected to the symptoms of impaired lung functions were smoking habit and nutritional status, and 4) the indicators of exposure contact amount which affected to the symptoms of impaired lung function were length of exposure and year of service. As a discussion, The longer the working period, the longer the worker is exposed to dust. The more exposure to dust that accumulates in the lungs which will later affect the capacity of lung function. A clinical manifestation disorder of decreased respiratory function will begin to appear and become permanent after exposure to dust between 10 years of work then one of the factors that can accelerate the decline in lung function is smoking. The results of this study indicate that individual characteristics and the number of exposure contacts have a positive effect on symptoms of impaired lung function, so it is necessary to conduct an evaluation regarding the risks experienced by workers. As a conclusion the symptom of impaired lung function on workers was caused by several factors as individual characteristic and amount of exposure contact.
\end{abstract}

Keywords: Impaired Lung Function, Exposure Contact, Individual Characteristic, Amount of Exposure Contact

\section{Introduction}

The industrial development in Indonesia is lately

\section{Corresponding Author:}

dr. Ancah Caesarina Novi Marchianti., Ph.D., Medical Doctor, Philosophy of Doctor, Faculty of Medicine, Jember University, Jawa Timur (Indonesia ). Email:ancah@unej.ac.id grown rapidly along with the increase of working population number in either formal or informal sector. The informal sector has a great role in developing countries, as Indonesia (1). The success of industry must be supported by an occupational health which can overcome many kinds of disease problem that are caused by occupational aspect, which aims to increase the work welfare and productivity. This consideration is in line with the Law of Occupational Health and Safety 
$1^{\text {st }}$ in 1970 and it has been approved by the Law $26^{\text {th }}$ in 2009 about occupational health, 164-165 $5^{\text {th }}$ article which have asserted that all workplaces must implement a good occupational health in either formal or informal sector. The worker will be at a high risk of many kinds of health problem which caused by work process, work environment, and work behavior, then it is potential to rise any occupational diseases or work-related disease. The occupational disease is a kind of disease caused by the worker's occupation or work environment. The less health work environment which is often filled with dust, steam, gas, chemicals, and other can cause productivity inconvenience or distraction and also interrupt the system of respiratory as symptom of impaired lung function ${ }^{(2)}$.

There are several researches which relate to the issue of occupational disease, is related to health problem and risk factor that occur to garment workers which shows the result that the respiratory disorder is most disease which occurs with percentage about $31,3 \%$, it is caused by neglected fiber, excessive inhalation of dust particle number which makes the workers to be more prone over lung disease ${ }^{(3)}$. The symptoms contain phlegmy cough with the most prevalent symptom about $17,1 \%$, followed by cough $15,8 \%$, asphyxia $11,6 \%$, and wheezing $7,8 \%$. The majority of workers, $66,7 \%-76,9 \%$ have complained for phlegmy cough along four days or more. Based on the above description, the purpose of this study was to analyze the symptoms of pulmonary function disorders and the factors that affect garment workers. UD. surabaya Jember region

\section{Methods}

This research was included into quantitative research, while the research design was analytic survey which referred to a type of research which was done without doing any intervention to the subject or non-experimental research which aimed to explain a condition or situation through cross-sectional design, which the independent variable and dependent variables that occurred on basic research object would be measured and collected on the same time. The location of research was at UD. Surabaya Rambipuji Sub-district, Jember District. The population of research were all garment workers with total sample of 108 respondents. Moreover, this research exerted primary data that were derived from the respondents who filled questionnaires that have been spread by the researchers. This research used regression of weight technique and AMOS software to analyze the data, it was aimed to examine how great the effect of two independent variable to the dependent one if it was due to the determinant coefficient value or estimate value.

\section{Research Findings}

The impaired lung function often indicated many kinds of symptom, the lung disease which caused by work was obviously the main cause of incapability, disability, lose, workday and death on the workers. The description of impaired lung function symptoms which suffered by the workers at UD. Surabaya Jember District would be presented below:

Table 1: Frequency Distribution of Individual Characteristics

\begin{tabular}{|c|c|c|c|}
\hline \multirow{2}{*}{ No } & Category & N & \% \\
\hline \multirow{3}{*}{1.} & \multicolumn{3}{|c|}{ Age } \\
\cline { 2 - 4 } & Productive Age $(17-47)$ & 100 & 92,6 \\
\cline { 2 - 4 } & Unproductive Age $(<17 \&>47)$ & 8 & 7,4 \\
\cline { 2 - 4 } & Total & 108 & 100 \\
\hline \multirow{3}{*}{2.} & Gender & \multicolumn{2}{|c|}{} \\
\cline { 2 - 4 } & Man & 47 & 43,5 \\
\cline { 2 - 4 } & Woman & 61 & 56,5 \\
\cline { 2 - 4 } & Total & 108 & 100 \\
\hline
\end{tabular}


Cont... Table 1: Frequency Distribution of Individual Characteristics

\begin{tabular}{|c|c|c|c|}
\hline \multirow{4}{*}{3.} & \multicolumn{3}{|c|}{ Smoking Habit } \\
\hline & Not Smoking & 68 & 61,1 \\
\hline & Smoking & 40 & 38,6 \\
\hline & Total & 108 & 100 \\
\hline \multirow{4}{*}{4.} & \multicolumn{3}{|c|}{ Nutritional Status } \\
\hline & Good Nutrition & 45 & 41,7 \\
\hline & Malnutrition & 63 & 58,3 \\
\hline & Total & 108 & 100 \\
\hline
\end{tabular}

Based on the table 1, the majority of garment workers at UD. Surabaya were in productive age (17-47 years old) as many as 100 workers with percentage of $92,6 \%$, gender of woman/female as many as 66 workers with percentage of $63,0 \%$, have no smoking habit as many as 68 workers with percentage of $61,1 \%$, and malnutrition status as many as 63 workers with percentage of $58,3 \%$.

Table 2: Distribution of Exposure Contact Amount on UD. Surabaya's Workers

\begin{tabular}{|c|c|c|c|}
\hline \multirow{2}{*}{ No } & Category & N & \% \\
\hline \multirow{3}{*}{1.} & \multicolumn{3}{|c|}{ Length of Exposure } \\
\cline { 2 - 4 } & Less than 8 Hours & 12 & 11,1 \\
\cline { 2 - 4 } & More than 8 Hours & 96 & 88.9 \\
\cline { 2 - 4 } & Total & 108 & 100 \\
\hline \multirow{3}{*}{2.} & \multicolumn{3}{|c|}{ Year of Service } \\
\cline { 2 - 4 } & Less than 5 Years & 25 & 23,1 \\
\cline { 2 - 4 } & More than 5 Years & 83 & 76,9 \\
\cline { 2 - 4 } & Total & 108 & 100 \\
\hline
\end{tabular}

Based on the table 2, it showed that the majority of workers at UD. Surabaya have contact of exposure in more than 8 hours and most of them have year of service along 5 years.

Table 3: Frequency Distribution of Impaired Lung Function Symptoms on UD. Surabaya's Garment Workers

\begin{tabular}{|c|c|c|c|}
\hline \multirow{2}{*}{ No } & Category & $\mathbf{n}$ & \% \\
\hline \multirow{3}{*}{1.} & \multicolumn{3}{|c|}{ Cough } \\
\cline { 2 - 4 } & No & 53 & 49,1 \\
\cline { 2 - 4 } & Yes & 55 & 50,9 \\
\cline { 2 - 4 } & Total & 108 & 100 \\
\hline
\end{tabular}


Cont ... Table 3 Frequency Distribution of Impaired Lung Function Symptoms on UD. Surabaya's Garment

\begin{tabular}{|c|c|c|c|}
\hline \multirow{4}{*}{2.} & \multicolumn{3}{|c|}{ Phlegmy } \\
\hline & No & 69 & 63,9 \\
\hline & Yes & 39 & 36,1 \\
\hline & Total & 108 & 100 \\
\hline \multirow{4}{*}{3.} & \multicolumn{3}{|c|}{ Phlegmy Cough } \\
\hline & No & 89 & 82,4 \\
\hline & Yes & 19 & 17,6 \\
\hline & Total & 108 & 100 \\
\hline \multirow{4}{*}{4.} & \multicolumn{3}{|c|}{ Asphyxia } \\
\hline & No & 36 & 33,3 \\
\hline & Yes & 72 & 66,7 \\
\hline & Total & 108 & 100 \\
\hline \multirow{4}{*}{5.} & \multicolumn{3}{|c|}{ Record of Chest Disease } \\
\hline & No & 103 & 95,4 \\
\hline & Yes & 5 & 4,6 \\
\hline & Total & 108 & 100 \\
\hline
\end{tabular}

Based on the table 3, the most dominant symptom felt by garment workers at UD. Surabaya was asphyxia in approximately 72 workers with percentage of $66,7 \%$.

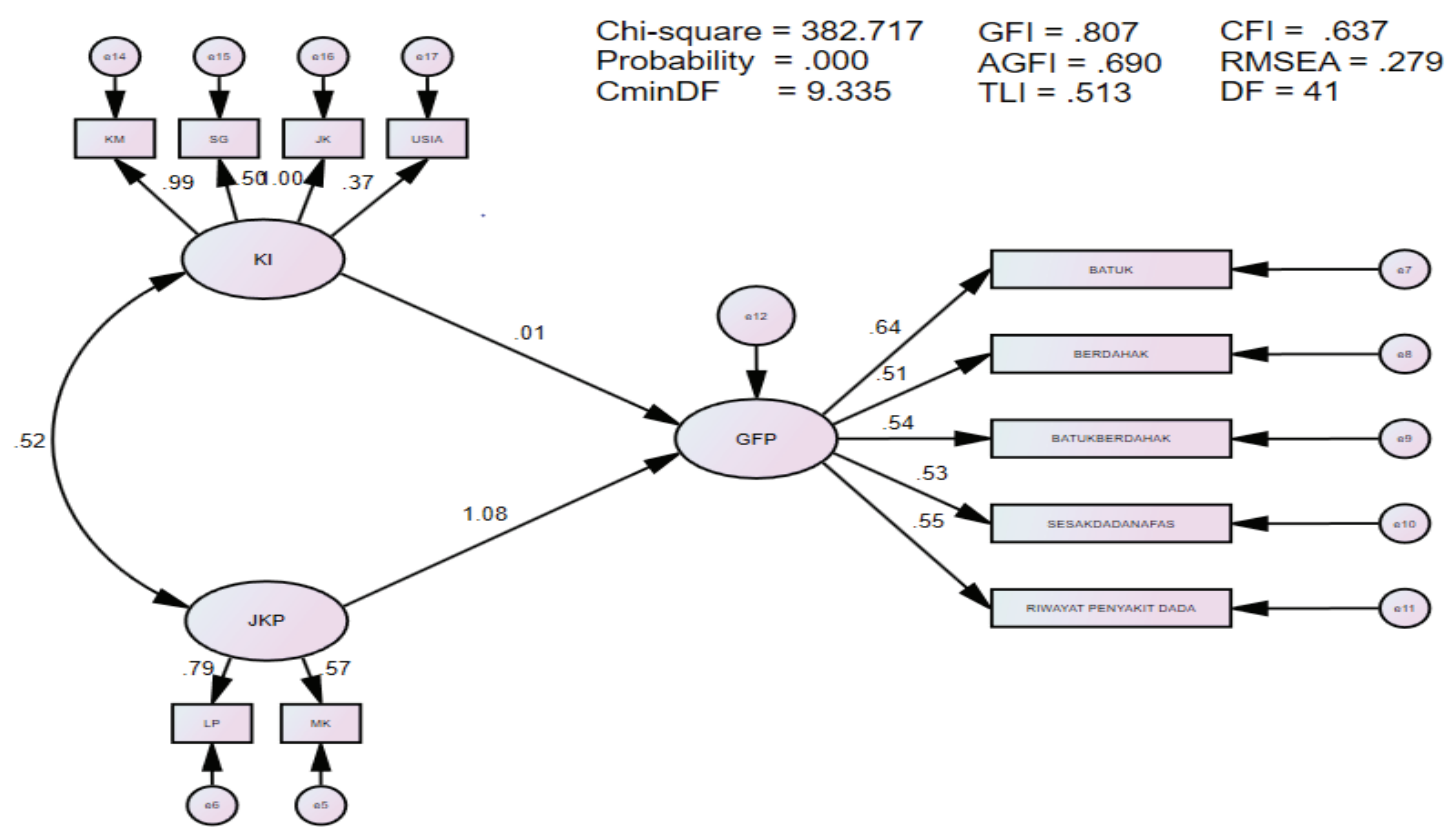

Figure 1 Analysis Using AMOS 23 


\begin{tabular}{|c|cc|c|c|c|}
\hline No. & Variabel & Koefisien R Square & Koefisien exp $\boldsymbol{\beta}$ & Signifikansi $\boldsymbol{\alpha}$ \\
\hline & & $\begin{array}{c}\text { Unstandardized Regression } \\
\text { Weight }\end{array}$ & $\begin{array}{c}\text { Standardized Regression } \\
\text { Weight }\end{array}$ & P-Value \\
\hline 1. & KI & à GFP & 0,019 & 0,015 & 0,913 \\
\hline 2. & JKP & $\backslash$ GFP & 1,189 & 1,084 & $* * *$ \\
\hline
\end{tabular}

NB: $* * *$ : The probability of getting a critical ratio as large as 4.166 in absolute value is less than 0.001 . In other words, the regression weight for JKP in the prediction of GFP is significantly different from zero at the 0.001 level (two-tailed).

\section{Discussion}

There were a number of factors that affected the symptoms of impaired lung function, one of them was symptom of impaired lung function because of dust and chemicals factor. The indoor air pollution was harmful for the workers' health. The other factors which affected the symptom of impaired lung function were individual characteristic and exposure contact ${ }^{(5)}$. A factor that was able to speed the decline of lung function was smoking habit. The smoking habit affected to rise impairment on lung function. The individual who were smoking for more than 10 years and got used to smoke with the amount of 1-10 cigarette stick per day would tend to suffer degradation of lung function ${ }^{(6)}$. Epidemiologically, the nutritional status and food intake which were related to individual need of energy would related to anatomical growth and body physiology, particularly for respiratory tract, which then affected the muscle mass strength to pump oxygen maximally to whole body, control respiratory rate, and form immunology mechanism within the body as a prevention of other lung disease attacks ${ }^{(7)}$. The gender also determined different lung capacity. The lung volume and capacity on woman was approximately $20-25 \%$ smaller than on man. The average of lung vital capacity on adult man was approximately 4,8 liter and on adult woman was approximately 3,1 liter (8).

A damage that caused by dust factor was the consequence of exposure length or contact with dust ${ }^{(9)}$. The majority of workers who have complaint of impaired lung function were the workers who have exposure length in more than 8 hours. The longer the workers worked in that workplace, it would enable the workers to get the longer exposure time than the workers who worked for relatively shorter exposure time. There was a relation found between year of service and lung function disorder. The workers who had year of service for more than 5 years would have risk 13,5 times bigger to suffer lung function impairment than those who worked for less than 5 years of service ${ }^{(10)}$.

The figure 1 illustrated that the path coefficient value could affect the individual to get symptoms of impaired lung function in approximately 0,07 (positive). Thus, it could be summed up that H1 was approved with a statement that the individual characteristic could deliver positive effect to the symptom of lung function disorder on garment workers at UD. Surabaya Jember District. Next, the figure 4.1 also showed that the path coefficient value could affect the amount of exposure contact to cause symptom of impaired lung function in approximately 0,15 (positive). In short, it was concluded that $\mathrm{H} 1$ was approved with a statement that the amount of exposure contact could have positive effect to cause symptom of impaired lung function on garment workers at UD. Surabaya Jember. Furthermore, the indicators of individual characteristic which affected to the symptom of lung function disorder were smoking habit and nutritional status. While, the indicators of exposure contact amount which affected to the symptom of lung function disorder were exposure time and year of service.

The results of this study indicate that individual characteristics and the number of exposure contacts have a positive effect on symptoms of impaired lung function, so it is necessary to conduct an evaluation regarding the risks experienced by workers. It is necessary to take 
measures to reduce the risk of exposure by preparing personal protective equipment for workers.

\section{Conclusion}

The symptom of impaired lung function on workers was caused by several factors as individual characteristic and amount of exposure contact. The most influential variable which affected to the symptom of impaired lung function on workers was the amount of exposure contact.

\section{Conflict of Interest: None}

\section{Source of Funding: Self}

Ethical Clearance: This research has undergone an ethical test in ethics commission of health research of Dentistry Faculty, Jember University with this following registration number 852/UN25.8/KEPK/DL/20120.

\section{References}

1. Suci R.Mar'ih Koesomo widjojo. Practical Guide to Developing a Workload Analysis (1sted.). Jakarta: Penebar Suadaya:2017. p.20

2. Kementrian Kesehatan RI. Indonesia Health Profile 2017. Jakarta: Kemenkes RI. . 2018;7 (1) http:// www.depkes.go.id/resources/download/pusdatin/ profil-kesehatan-indonesia/Profil-KesehatanIndonesia-tahun-2017.pdf

3. Sreesupria P.R \&Pankaj B. Shah. Health problems and risk factors prevailing among garmentworkers in Tirupur, Tamil Nadu. International Journal of Community Medicine and Public Health Ravichandran SP et al. Int J Community Med Public Health. 2018 Jun;5(6):2400-2405.https://www.ijcmph.com/ index.php/ijcmph/article/view/2888

4. Ikhsan, Arfan. Environmental Management Accounting. First edition. Yogyakarta: Graha ilmu. Industri. Edition 2019. 2009. p.5 file://C:/Users/ user/Downloads/Analisis\%20Perkembangan $\% 20$ Industri\%20Edisi\%20I\%20-\%202019.pdf

5. Kemenkes RI No.1077/Menkes/per/v/2011. About Guidelines for Domestic Air Sanitation. Menteri Kesehatan. Jakarta: 2011. p.50

6. Nisa, K., Sidharti, L. dan Adityo, M. F. The Effect of Smoking Habits on Lung Function in Employees at the Rectorate Building, University of Lampung. Jurnal Kesehatan Unila 2015; 5(9): p.38-42.

7. Sari, D. P. P., Budiono dan Yunita, N. A. 2017. Factors Related to Impaired Lung Function in Female Workers in Praoe Lajar Cigarette Factory, Semarang, Central Java. Jurnal Kesehatan Masyarakat 2017; 5(5): 581-591.

8. Pearce. Evelyn C. Anatomy and Physiology for Paramedics. Jakarta: PT Gramedia. 2008. p.10

9. Sholihah, M. danTualeka, A. R. 2015. Study of Pulmonary Physiology and Smoking Habits of Workers Exposed to Dust at Construction Companies in Surabaya. The Indonesian Journal Of Occupational Safety And Health 4(1):2015. p.1-10.

10. Nafisa, R. S. F., Joko, T. dan Setiani, O. 2016. The Relationship of Exposure to Wood Dust in the Work Environment to Impaired Lung Function in Workers at PT. Arumbai Kasemba and, Banyumas. Jurnal Kesehatan Masyarakat; 4(5): 2016. p.178186. 